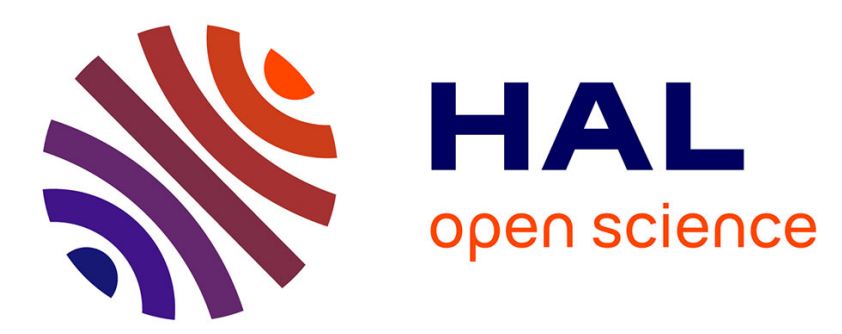

\title{
The role of nickel and titanium in the formation of ohmic contacts on p-type $4 \mathrm{H}-\mathrm{SiC}$
}

Farah Laariedh, Mihai Lazar, P. Cremillieu, J. Penuelas, J-L Leclercq, Dominique Planson

\section{- To cite this version:}

Farah Laariedh, Mihai Lazar, P. Cremillieu, J. Penuelas, J-L Leclercq, et al.. The role of nickel and titanium in the formation of ohmic contacts on p-type $4 \mathrm{H}-\mathrm{SiC}$. Semiconductor Science and Technology, 2013, 28 (4), 10.1088/0268-1242/28/4/045007 . hal-01627844

\section{HAL Id: hal-01627844 https://hal.science/hal-01627844}

Submitted on 9 May 2019

HAL is a multi-disciplinary open access archive for the deposit and dissemination of scientific research documents, whether they are published or not. The documents may come from teaching and research institutions in France or abroad, or from public or private research centers.
L'archive ouverte pluridisciplinaire HAL, est destinée au dépôt et à la diffusion de documents scientifiques de niveau recherche, publiés ou non, émanant des établissements d'enseignement et de recherche français ou étrangers, des laboratoires publics ou privés. 


\title{
The role of nickel and titanium in the formation of ohmic contacts on p-type $4 \mathrm{H}-\mathrm{SiC}$
}

\author{
F. Laariedh ${ }^{1}$, M. Lazar ${ }^{1 *}$, P. Cremillieu ${ }^{2}$, J. Penuelas ${ }^{2}$, J.-L. \\ Leclercq $^{2}$ and D. Planson ${ }^{1}$ \\ ${ }^{1,2}$ Université de Lyon, CNRS, \\ ${ }^{1}$ INSA-Lyon, Laboratoire AMPERE, UMR 5005, F-69621 Villeurbanne, \\ France \\ ${ }^{2}$ ECL-Lyon, Institut des Nanotechnologies de Lyon (INL), UMR 5270, F- \\ 69134 Ecully, France \\ *E-mail: mihai.lazar@insa-lyon.fr
}

Keywords: Silicon Carbide, Ohmic contact resistance, nickel silicide, titanium silicon carbide, SIMS, EDX and XRD.

\begin{abstract}
The formation of low resistivity ohmic contacts to p-type $4 \mathrm{H}-\mathrm{SiC}$ is achieved. Transfer Length Method (TLM) based-structures were fabricated on $0.8 \mu \mathrm{m}$-thick epitaxial ptype Silicon Carbide (4H-SiC) layers. TLM metal patterns were obtained by a lift-off procedure and electron beam deposition of $\mathrm{Ni}, \mathrm{Ti}$ and $\mathrm{Al}$. The electrical properties of the contacts were examined using current/voltage measurements. Contact resistivity as a function of annealing was investigated over the temperature range from $700^{\circ} \mathrm{C}$ to $1000^{\circ} \mathrm{C}$. The lowest contact resistivity of $1.5 \times 10^{-5} \Omega . \mathrm{cm}^{2}$ was obtained for Ni/Ti/Al/Ni contact after annealing at $800^{\circ} \mathrm{C}$ for $90 \mathrm{~s}$. Using Secondary Ion Mass Spectrometry (SIMS), Energy-Dispersive X-Ray spectroscopy (EDX) and X-Ray Diffraction (XRD) measurements we quantitatively and qualitatively determined the formation and the nature of the ohmic contact to p-type $\mathrm{SiC}$.
\end{abstract}

PACS: $85.40 . \mathrm{Ls}, 73.40 . \mathrm{Cg}, 68.35 . \mathrm{bd}$

\section{Introduction}

The inherent properties of silicon carbide ( $\mathrm{SiC}$ ) such as wide bandgap, high thermal conductivity, and high breakdown voltage make it a very promising material for high power, high temperature and highfrequency device applications where $\mathrm{Si}$ and GaAs devices cannot be used. One of the most critical issues currently limiting the device processing is the manufacturing of reliable and low resistance ohmic contacts on silicon carbide [1-3]. Since the work function difference between metals and p-type $\mathrm{SiC}$ is extremely large, it is very difficult to form ohmic contacts. To answer to this problem, it is necessary to choose metals with low Schottky barrier and to overdope p-type $\mathrm{SiC}$ layer close to the metal contact. To form such narrower bandgap interface SiC/Contact, many materials have been examined. Among them, nickel, titanium and aluminium have attracted more attention.

$\mathrm{Ni}-\mathrm{Ti}$ alloy contacts which have been successfully used in the fabrication of ohmic contacts on n-type SiC layers [4] present specific contact resistances on p-type $\mathrm{SiC}$ layers in the order of $10^{-3}$ $\Omega . \mathrm{cm}^{2}$ [5] which are not enough low in order to fabricate reliable power or high temperature SiC devices. To improve the quality of these contacts, aluminium based materials such as Ti/Ni/Al, Ni-Al and Al-Ti [6-9], have been used resulting in specific contact resistances lower than $1.10^{-4} \Omega_{.} . \mathrm{cm}^{2}$. For the Al-Ti alloy, the ohmic behaviour is obtained but remains very sensitive to the quantity and 
stability of the aluminium layer. The composition (in weight) of $\mathrm{Al} 90 \%$ - Ti $10 \%$ yielded to the lowest specific resistance of $10^{-6} \Omega \cdot \mathrm{cm}^{2}$ however this result was not reproducible [10,11]. On the other hand the composition $\mathrm{Al}(70 \%)$ - $\mathrm{Ti}(30 \%)$ represents the best choice for a good and reproducible contact with a specific resistance of the order of $10^{-5} \Omega \cdot \mathrm{cm}^{2}[12,13]$.

In such high Al-content contacts, overdoping of the $\mathrm{SiC} /$ metal contact interface is obtained producing a heavily p-type doped region and yielding to low resistance contacts [11,14]. Al seems to create intrusions into the $\mathrm{SiC}$, as its diffusion is still very difficult ${ }^{11}$. It has also been noted the possibility of thermal exo-evaporation of some $\mathrm{Al}$ during annealing performed at around $1000^{\circ} \mathrm{C}[15]$. Thus, other metals have to be added to the interface in order to improve in depth-penetration of dopants into the SiC. Titanium is added to lower the extremely high thermodynamic driving force for oxidation of $\mathrm{Al}$ [16]. Alternative materials such as co-evaporation of $\mathrm{TiC}$ and sputtered $\mathrm{TiW}$ have been studding to form ohmic contacts on high doped p-type SiC obtaining specific ohmic resistance of

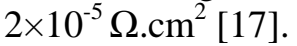

In this article we present the results of $\mathrm{Al} / \mathrm{Ti} / \mathrm{Ni}$-based low resistive ohmic contacts to $\mathrm{p}^{+}$-type epilayers of $4 \mathrm{H}-\mathrm{SiC}$. We selected $\mathrm{Ni}$ as the key contact element. Ni was reported to react at low temperatures as $500^{\circ} \mathrm{C}$ with $\mathrm{SiC}$ by forming $\mathrm{Ni}_{2} \mathrm{Si}$ silicide $[18,19]$. Ohmic contacts realized at low temperatures have a particular interest in the development of SiC MOSFET technology. Ti was added to the $\mathrm{Ni} / \mathrm{Al}$ contacts to prevent the formation of unreacted interfacial carbon atoms $[14,20]$. Our study proposed to identify the role of each element and the phase formed at the metal/semiconductor interface by complementary electrical and physic-chemical analyses. "This paper presents our extended results on the metallization process in order to obtain reliable ohmic contacts operating up to $300^{\circ} \mathrm{C}$. The first results have been reported in Ref. [21].

\section{Experimental}

Transfer Length Method (TLM) structures, were fabricated on $0.8 \mu$ m-thick epitaxial p-type $\left(\mathrm{N}_{\mathrm{A}}=3\right.$ to $\left.4.10^{19} \mathrm{~cm}^{-3}\right)$ layers isolated from the substrate by a $12 \mu \mathrm{m}$ thick n-type epilayer $\left(\mathrm{N}_{\mathrm{D}}=5.10^{15} \mathrm{~cm}^{-3}\right.$ - the epitaxial data were furnished by the epilayer supplier). The TLM structures were also isolated in lateral by forming $2 \mu \mathrm{m}$ deep trenches realized by reactive ion etching (RIE) with $\mathrm{SF}_{6} / \mathrm{O}_{2}$. After degreasing in organic solvents, rinsing in de-ionized water (DI) and cleaned with standard RCA solution, the samples were finally dipped in BOE (Buffered Oxide Etchant) solution for 2 min at room temperature.

TLM patterns were then defined by lift-off of $\mathrm{Ni}, \mathrm{Ti}$ and $\mathrm{Al}$ layers deposited on the $\mathrm{SiC}$ substrates by electron-beam evaporation in a high vacuum chamber where the base pressure was below $1.10^{-7} \mathrm{mbar}$, and the pressure during deposition was below $5.10^{-7} \mathrm{mbar}$. Thicknesses of the metal layers are given in table 1 and were double checked via quartz microbalance and X-ray reflectivity measurements (not shown here).

The contacts were annealed under Ar atmosphere with JIPELEC rapid thermal annealing (RTA) furnace on a graphite holder. The annealing procedure is performed in several steps. The first one consists in a relatively low temperature ramping up to $350^{\circ} \mathrm{C}$, then the temperature is set to the contact formation temperature, varying from 700 to $1000^{\circ} \mathrm{C}$, landing at this temperature during $90 \mathrm{~s}$. Prior to metal annealing the furnace was cleaned with successively vacuum purges.

Electrical characterization after annealed contacts was performed by current-voltage (I-V) measurements. The specific contact resistances were extracted by a Transfer Length Method (TLM), with $80 \times 500 \mu \mathrm{m}^{2}$ metal patterns with spacing distances of $25,35,45,55,65$ and $75 \mu \mathrm{m}$. The distance from the TLM metal patterns to the etched mesa edges is $20 \mu \mathrm{m}$ which is insignificant compared to the metal patterns width $(500 \mu \mathrm{m})$ and allows us to consider TLM one-dimensional model and to omit the lateral current crowding [12].

Using Secondary Ion Mass Spectrometry (SIMS) with a CAMECA IMF and an $\mathrm{O}^{2+}$ primary ion beam, Energy-Dispersive X-Ray spectroscopy (EDX) with a SEM Philips CM120 and X-ray Diffraction measurements before and after annealing, we investigate qualitatively and quantitatively the formation of the contacts and their evolution at the SiC/contact interface. X-ray diffraction measurements were performed with a diffractometer equipped with a rotating anode operating at 9 $\mathrm{kW}$. The X-ray were monochromatized using a double $\mathrm{Ge}(400)$ crystal which selects the $\mathrm{Cu}$ kalphal radiation ( wavelength $=1.5406 \AA$ ). 
Table 1. Thicknesses of $\mathrm{Ni}, \mathrm{Al}$, and $\mathrm{Ti}$ layers and acceptor concentrations in $\mathrm{SiC}$ substrates.

\begin{tabular}{cc}
\hline $\begin{array}{c}\text { Composition of the } \\
\text { metal contact }\end{array}$ & $\begin{array}{c}\text { Thickness of the } \\
\text { metal contact }(\mathrm{nm})\end{array}$ \\
\hline $\mathrm{Ti} / \mathrm{Al} / \mathrm{Ti} / \mathrm{Ni}$ & $5 / 60 / 30 / 100$ \\
$\mathrm{Ni} / \mathrm{Ti} / \mathrm{Al}$ & $25 / 50 / 300$ \\
$\mathrm{Ni} / \mathrm{Ti} / \mathrm{Al}$ & $12.5 / 25 / 150$ \\
$\mathrm{Ni} / \mathrm{Ti} / \mathrm{Al} / \mathrm{Ni}$ & $12.5 / 50 / 300 / 12.5$ \\
$\mathrm{Ni} / \mathrm{Ti} / \mathrm{Al} / \mathrm{Ni}$ & $10 / 40 / 240 / 10$ \\
$\mathrm{Ni} / \mathrm{Ti} / \mathrm{Al} / \mathrm{Ni}$ & $5 / 20 / 120 / 5$ \\
\hline
\end{tabular}

\section{Results and discussion}

First, we have noted that despite the high doping level at $3.10^{19} \mathrm{~cm}^{-3}$ of our p-type $4 \mathrm{H}-\mathrm{SiC}$ layers, the as-deposited metal contacts formed a Schottky barrier. After 90 s annealing at $700{ }^{\circ} \mathrm{C}$ of the contacts, typical I-V characteristics are given in Figure 1 for the three families of the contact alloys presented in Table1. A linear I-V characteristic can be seen indicating that the contact becomes ohmic, only if the $\mathrm{Ni}$ layer is present at $\mathrm{SiC}$ surface for the temperatures as low as $700^{\circ} \mathrm{C}$.

For the metallic contacts with $\mathrm{Al}$ on top, the presence of an on-surface insulating layer has been observed whatever the annealing temperature. This makes difficult the measure of the contacts and the electric characterization which can be only made once this layer is removed by mechanical action (we scratch these contacts with the point) or by a long $\mathrm{Ar} / \mathrm{H}_{2}$ RIE plasma. To solve this problem, the $\mathrm{Ni} / \mathrm{Ti} / \mathrm{Al}$ contact was capped with a top layer of $\mathrm{Ni}$ avoiding the oxidation of the aluminium or other phenomenon responsible of this insulating layer in surface.

\section{I (A)}

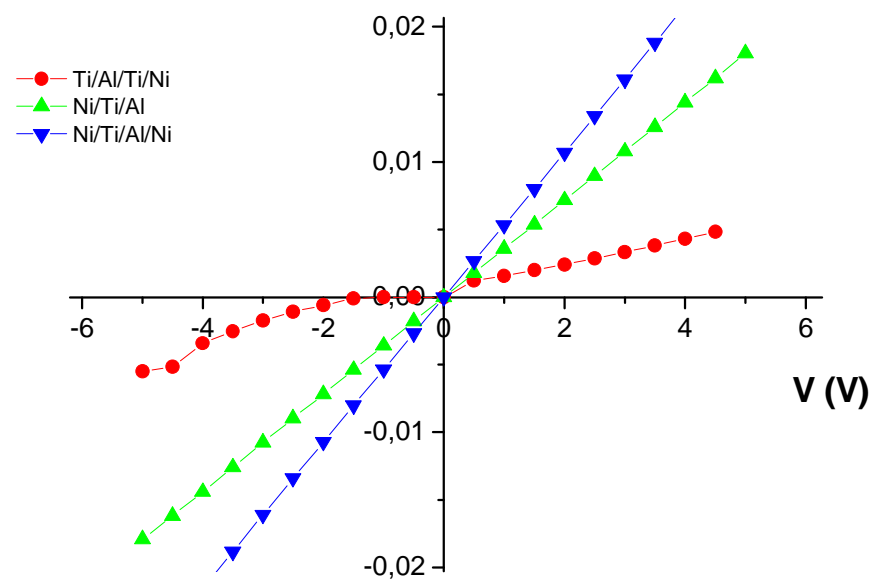

Figure 1. Typical I-V characteristics of the contacts for the three different families of the used alloys obtained after $90 \mathrm{~s}$ annealing at $700^{\circ} \mathrm{C}$.

Regarding these first experiments which show after annealing a non ohmic contact with the $\mathrm{Ti} / \mathrm{Al} / \mathrm{Ti} / \mathrm{Ni}$ alloy and the presence of an insulated layer on the top of the contacts with $\mathrm{Ni} / \mathrm{Ti} / \mathrm{Al}$ initial stacking sequence, we selectively focused on $\mathrm{Ni} / \mathrm{Ti} / \mathrm{Al} / \mathrm{Ni}$ contacts by studying the effects of the annealing temperature (figure. 2). The dependence of the electrical properties of the $\mathrm{Ni} / \mathrm{Ti} / \mathrm{Al} / \mathrm{Ni}$ contacts on the annealing conditions was studied over the $700^{\circ} \mathrm{C}$ to $900^{\circ} \mathrm{C}$ temperature range. The specific resistance, and then the contact resistivity, was observed to vary with the annealing temperature. The specific resistance decreases with increasing annealing temperature until $800^{\circ} \mathrm{C}$, then it increases with the temperature indicating, probably, the deterioration of the contact. The lowest contact resistance of $1.5 \times 10^{-5} \Omega . \mathrm{cm}^{2}$ was obtained at $800^{\circ} \mathrm{C}$. 

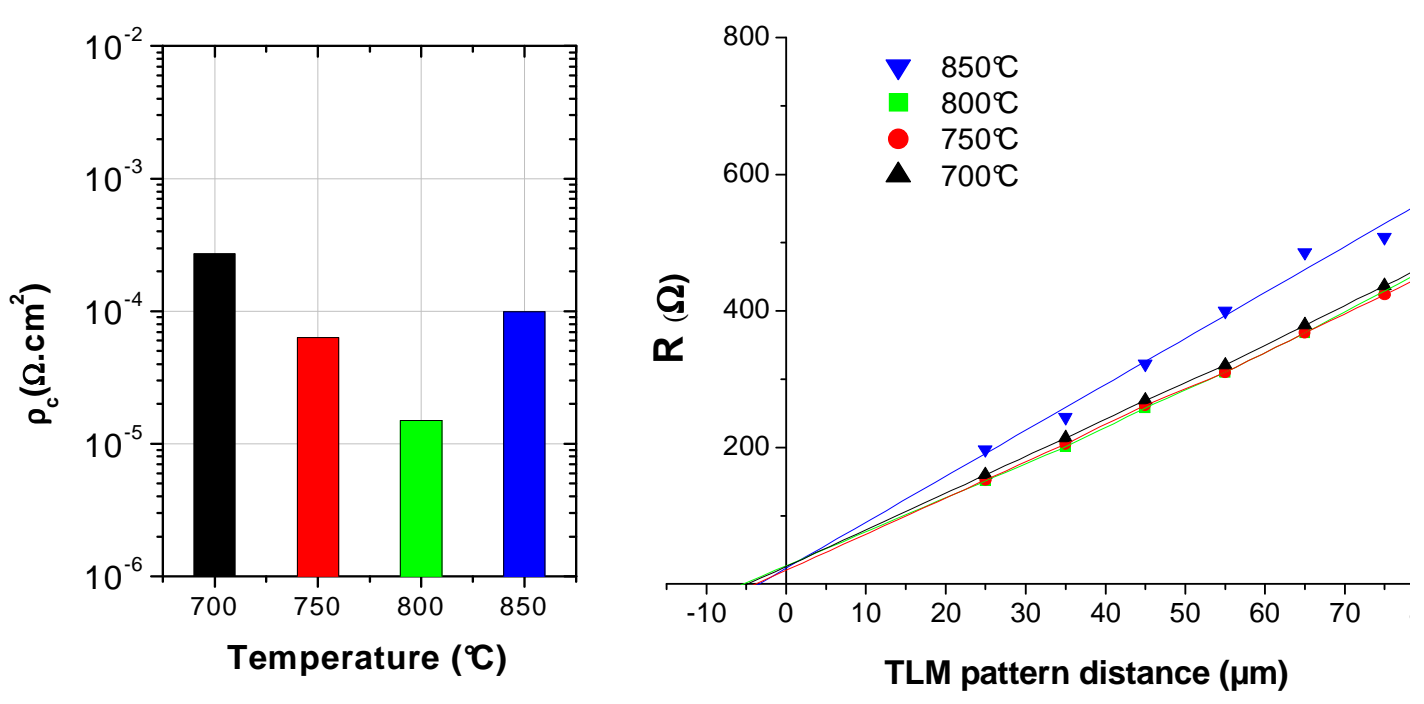

Figure 2. Resistance extracted versus distance between TLM pads of the $\mathrm{Ni}(10) / \mathrm{Ti}(40) / \mathrm{Al}(240) / \mathrm{Ni}$ $(10 \mathrm{~nm})$ contacts and dependence of the specific contact resistance from annealing temperatures at 700 to $850^{\circ} \mathrm{C}$.

Considering the capping effect of $\mathrm{Ni}$ on top of the Ni-Ti-Al contacts, it is important to note that a thickness of $5 \mathrm{~nm}$ is not sufficient to avoid the presence of on-surface insulating layer. The resistances extracted from the extreme patterns of the TLM are not aligned with the inner ones as those presented in figure 2. Insulated layers were formed at the edge of TLMs metal patterns close to the etched mesas.

Then physico-chemical studies have been conducted to identify the chemical composition (and then the origin) of this insulating layer at the top contacts. These physico-chemical analyses allow also us to identify the phases formed at the $\mathrm{SiC}$ interface which could be considered as responsible of the ohmic behaviour of our contacts.

At first, the contact element profile was investigated by SIMS before and after annealing at $800^{\circ} \mathrm{C}$. Before the annealing we can see as expected the successive metallic elements $\mathrm{Ni}(5) / \mathrm{Ti}$ (20)/ $\mathrm{Al}(120) / \mathrm{Ni}(5 \mathrm{~nm})$ stacking from the surface to the $\mathrm{SiC}$ interface corresponding to their respective deposited position (figure. $3 \mathrm{a}$ ).

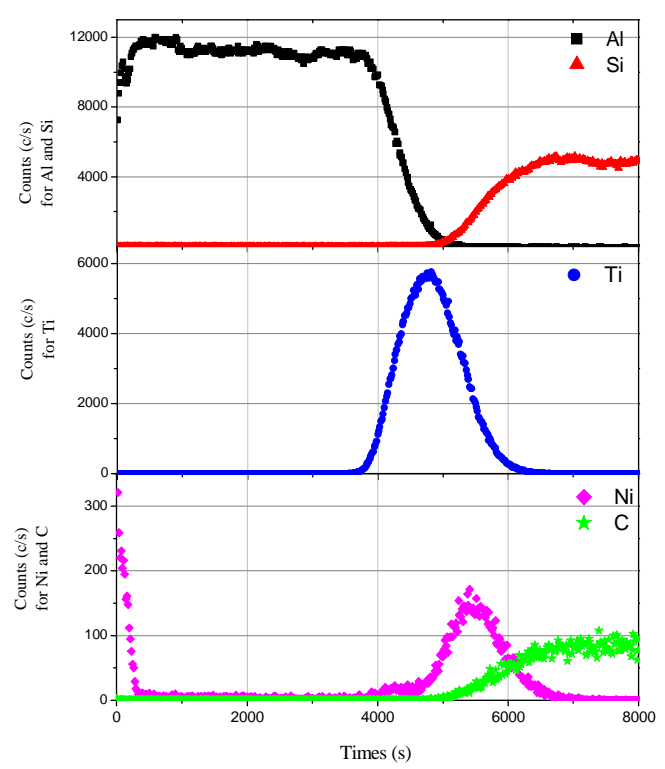

a)

Figure 3. SIMS spectra for measurements a) before and b) after annealing at $800^{\circ} \mathrm{C}$ of $\mathrm{Ni} / \mathrm{Ti} / \mathrm{Al} / \mathrm{Ni}$ contacts

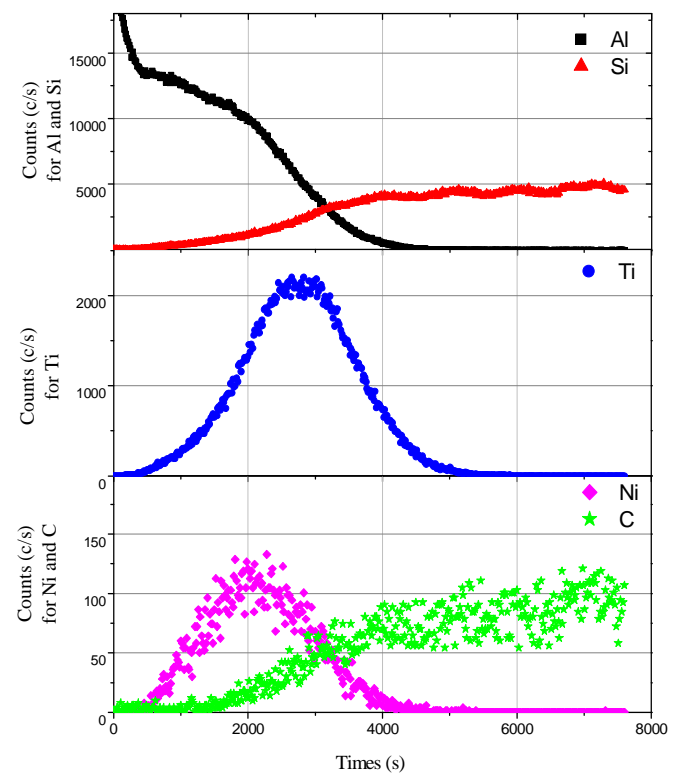

b) on $4 \mathrm{H}-\mathrm{SiC}$ samples. 
The RTA process leads to the redistribution of the metallic elements into the $\mathrm{SiC}$ (figure. $3 \mathrm{~b}$ ). It shows the formation of a layered contact structure having two clearly regions. The top surface is enriched with $\mathrm{Al}$, the $\mathrm{Al}$ profile geometry suggesting a possible evaporation in surface. $\mathrm{Al}, \mathrm{Ni}$ and $\mathrm{Ti}$ have penetrated in depth in the $\mathrm{SiC}$. This interacting zone close to the $\mathrm{SiC}$ interface should be significative of the probable formation of metallic silicides and/or carbides alloys such as $\mathrm{Ni}_{2} \mathrm{Si}, \mathrm{TiC}$ and $\mathrm{Ti}_{3} \mathrm{SiC}_{2}$ which can favour the ohmic behaviour. We should also note the absence of a carbonic layer at the $\mathrm{SiC}$ interface, no peak of the $\mathrm{C}$ is detected by our SIMS measurements and the plateau profile of the $\mathrm{C}$ is escorted by the $\mathrm{Si}$ plateau profile. The carbonic layer at the $\mathrm{SiC}$ interface is often reported to be responsible for the high values of the specific ohmic contact resistivity [14]. This must be correlated with the presence of the Ti which is a key-element for the formation of Ti-based carbides. Compared to the results presented by Vassilevski et al [7], our profiles of Ti and C are not correlated. We can therefore suppose that Ti-Si carbide have been formed instead of TiC. As mentioned by Johnson et al [9], $\mathrm{Ti}_{3} \mathrm{SiC}_{2}$ ternary phase presents a significant effect in the formation of ohmic contact to p-type $\mathrm{SiC}$ by forming a narrow-gap interfacial alloy reducing the Schottky barrier height at the metal-SiC interface.

On the other hand we remark the Ni profile evolution approaching to that of the Si which can be explained probably by the formation of $\mathrm{Ni}_{2} \mathrm{Si}$. Our electrical measurements on TLMs structures show how important the presence of the $\mathrm{Ni}$ at the metal-SiC interface can be for the formation of ohmic contacts for annealing temperatures as low as $700^{\circ} \mathrm{C}$. The $\mathrm{Ni}_{2} \mathrm{Si}$ alloy already mentioned to be formed at this low temperature $[18,19]$, seems to play a role in the formation of ohmic contact on p-type $\mathrm{SiC}$ as for the contacts on n-type $\mathrm{SiC}$.

The composition of the intermetallic phases was studied by X-ray diffraction analysis (XRD) in order to confirm the presence of these alloys at the $\mathrm{SiC}$ interface. The X-ray spectra of $\mathrm{Ni} / \mathrm{Ti} / \mathrm{Al} / \mathrm{Ni}$ films deposited on $4 \mathrm{H}-\mathrm{SiC}$ before and after annealing at $800^{\circ} \mathrm{C}$ are shown in figure 4 . Before annealing, several Bragg reflections are identified corresponding to the $\mathrm{SiC}(0001)$ substrate and the non-alloyed bulk phase of $\mathrm{Ti}, \mathrm{Al}$ and $\mathrm{Ni}$. Epitaxial relationships of the deposited metals were not investigated. After high-temperature annealing at $800^{\circ} \mathrm{C}$, we can observe the presence of numerous peaks revealing the formation of several intermetallic phases such as $\mathrm{Ti}_{3} \mathrm{SiC}, \mathrm{Ni}_{2} \mathrm{Si}, \mathrm{Al}_{2} \mathrm{Ti}$ or $\mathrm{NiAl}_{3}$. These measurements are in good agreement with our previous results from SIMS, these intermetallic phases, especially $\mathrm{Ti}_{3} \mathrm{SiC}$ and $\mathrm{Ni}_{2} \mathrm{Si}$, seem to favour the formation of the ohmic contact.

Moreover, the creation of Al-Ti and Al-Ni phases limit the presence of elementary $\mathrm{Al}$ on top of the surface and then its oxidation leading to the increase of contact resistance.

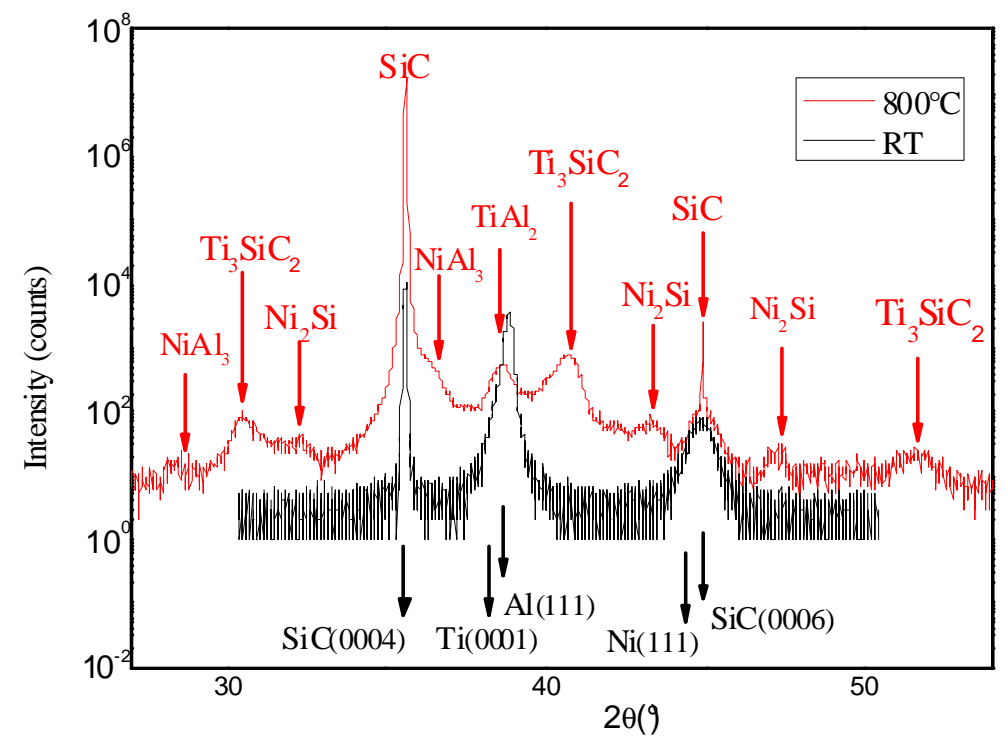

Figure 4. $\mathrm{X}$-ray spectra of $\mathrm{Ni} / \mathrm{Ti} / \mathrm{Al} / \mathrm{Ni}$ contacts on $4 \mathrm{H}-\mathrm{SiC}$ before and annealed at $800^{\circ} \mathrm{C}$.

This oxidation which creates the insulating layer on the top of the contacts was also confirmed by EDX chemical analyses. The concentrations of every constituting metal contact elements are given in table 2 before and after annealing. Surprisingly, we have found after annealing the presence of an 
important amount (up to 29 at $\%$ ) of $\mathrm{O}_{2}$. Whatever, this oxygen presence did not influence the ohmic property of the $\mathrm{Ni} / \mathrm{Ti} / \mathrm{Al} / \mathrm{Ni}$ contacts as we showed by electrical measurements.

Table 2. EDX results after annealing $\mathrm{Ni}(5 \mathrm{~nm}) / \mathrm{Ti}(20 \mathrm{~nm}) / \mathrm{Al}(120 \mathrm{~nm}) / \mathrm{Ni}(5 \mathrm{~nm})$ contacts on $4 \mathrm{H}-\mathrm{SiC}$ samples.

\begin{tabular}{|c|c|c|c|c|c|c|}
\hline & \multicolumn{2}{|c|}{ Before annealing } & \multicolumn{2}{|c|}{$\begin{array}{c}\text { After annealing Ar at } \\
3.310^{-3} \mathrm{mbar}\end{array}$} & \multicolumn{2}{|c|}{$\begin{array}{c}\text { After annealing under } \mathrm{A} \\
\text { at } 10^{3} \mathrm{mbar}\end{array}$} \\
\hline & w\% & at $\%$ & $\mathrm{w} \%$ & at $\%$ & $\mathrm{w} \%$ & at $\%$ \\
\hline C & 8.82 & 19.70 & 4.42 & 8.50 & 7.04 & 15.82 \\
\hline O & 0.00 & 0.00 & 20.09 & 28.98 & 2.99 & 5.04 \\
\hline Al & 34.86 & 34.65 & 45.40 & 38.84 & 25.69 & 25.72 \\
\hline Si & 39.83 & 38.02 & 27.62 & 22.70 & 47.52 & 45.70 \\
\hline Ti & 1.00 & 0.56 & 0.00 & 0.00 & 0.00 & 0.00 \\
\hline $\mathrm{Ni}$ & 15.49 & 7.07 & 2.46 & 0.97 & 16.77 & 7.72 \\
\hline
\end{tabular}

Nevertheless the amount of $\mathrm{O}_{2}$ in our contacts was decreased to 5 at\% (table 2) by increasing the $\mathrm{Ar}$ pressure from $3.310^{-3}$ mbar to one atmosphere $\left(10^{3} \mathrm{mbar}\right)$ during our RTA process.

We remark that the amount of the Ni detected by the EDX analyses drastically decreases after annealing in $\mathrm{Ar}$ at $3.310^{-3} \mathrm{mbar}$ while the $\mathrm{Al}$ concentration increases. The formation of the insulated layer in surface prevents the detection of the $\mathrm{Ni}$ in depth by the EDX teardrop-shaped volume. Nevertheless after annealing under $\mathrm{Ar}$ at one atmosphere $\left(10^{3} \mathrm{mbar}\right)$ without insulated layer in surface, the amount of the $\mathrm{Ni}$ found by EDX is close to the concentration before annealing. Concerning the concentration of Ti the values we obtained are very small before and after annealing due to its deeper localization compared with $\mathrm{Ni}$ (as showed by SIMS analyses), closer to the $\mathrm{SiC}$ interface after annealing and enough far from the EDX teardrop-shaped volume detection limit.

Considering our optimal ohmic contact configuration, with the $\mathrm{Ni}(10) / \mathrm{Ti}(40) / \mathrm{Al}(240) / \mathrm{Ni}(10 \mathrm{~nm})$ stacking annealed at $800^{\circ} \mathrm{C}$, finally a thermal stress-test has been applied between $25^{\circ} \mathrm{C}$ to $300^{\circ} \mathrm{C}$. The contact reliability at high temperature is usually considered as the crucial factor determining the limitation of a contact system for power device applications. The experimental results are presented in Figure 5. We note that the measured specific contact resistances are higher that those reported in Figure 2. This is due to the experimental setup during which the TLM patterns were damaged during the probe tips manipulation (the contacts with the TLM patterns must be made and released for each measurement temperature). We preferred to not add a surmetallisation layer in order to characterize only our stacking annealed alloy

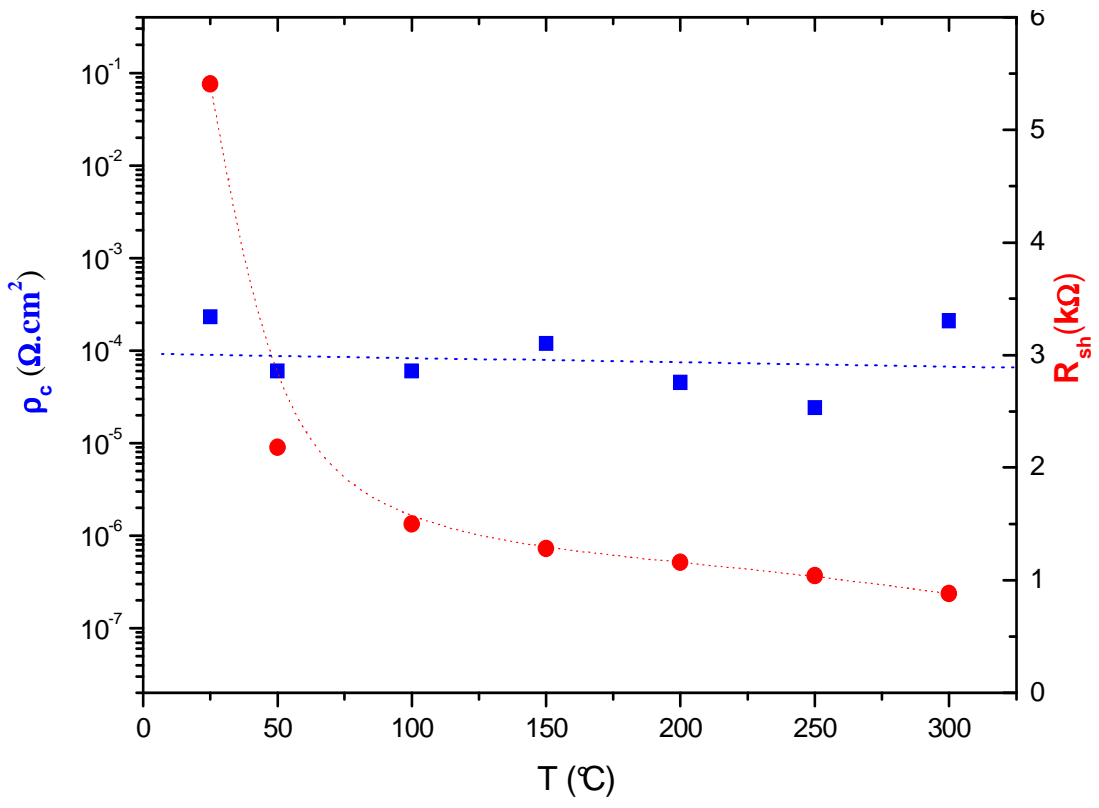

Figure 5. The dependence of the specific contact resistance and sheet resistance under the thermal stress for the $\mathrm{Ni}(10) / \mathrm{Ti}(40) / \mathrm{Al}(240) / \mathrm{Ni}(10 \mathrm{~nm})$ contacts annealed at $800^{\circ} \mathrm{C}$ in $\mathrm{Ar}$ 
As shown in the figure 5, the specific contact resistance did not varied under the thermal stress. This can be attributed to the formation of intermetallic phases which are stables up to $300^{\circ} \mathrm{C}$.

We also observe a normal decrease of the sheet resistance $\mathrm{R}_{\mathrm{sh}}$ due to the ionization of $\mathrm{Al}$ and thus to the increase of the holes concentration which is a typically behaviour of wide bandgap semiconductors with incomplete ionisation of the dopants at room temperature.

\section{Summary}

Low resistivity $\mathrm{Ni} / \mathrm{Ti} / \mathrm{Al} / \mathrm{Ni}$-based ohmic contacts on p-type doped $\mathrm{SiC}$ were investigated and discussed. The lowest contact resistivity of $1.5 \times 10^{-5} \Omega . \mathrm{cm}^{2}$ has been obtained after annealing at $800^{\circ} \mathrm{C}$ for 90 s in argon atmosphere.

The results of this study show that the adding of Nickel into the Ti-Al contact composition at the $\mathrm{SiC}$ interface is critical to obtain good ohmic contacts with low access resistance limiting the potential oxidation of the elementary Al.

The rapid thermal annealing of multilayer $\mathrm{Ni} / \mathrm{Ti} / \mathrm{A} 1 / \mathrm{Ni}$ metal composition led to the formation of $\mathrm{Ni}_{2} \mathrm{Si}, \mathrm{Ti}_{3} \mathrm{SiC}_{2}, \mathrm{Al}_{2} \mathrm{Ti}$ and $\mathrm{NiAl}_{3}$ intermetallic phases. This ohmic contact is thermally stable up to $300^{\circ} \mathrm{C}$.

\section{Acknowledgements}

The authors would like to acknowledge the Linkopings Universitet represented by Dr Jawad ul Hassan and Prof Anne Henry for epitaxial growth. The authors also wish to thank Dr Christiane Dubois from INL laboratory for SIMS analysis, Dr Davy Carole and Stéphane Berckmans from LMI laboratory for EDX analysis, the financial support by the USAR-ANR, is gratefully acknowledged. 


\section{References}

[1] Cooper J A, Melloch M R, Woodall J M, Spitz J and Schocn K, Henning J P, J 1998 Mat. Sci. Forum. 264-268 895.

[2] Rottner K, Frischholz M, Myrtveit T, Mou D, Nordgren K, Henry A, Hallin C, Gustafsson U and Schoner A, 1999 Mater. Sci. Eng. B 61330.

[3] Friedrichs P 2007 CS. MANTECH Conference. (Austin Texas USA) p221.

[4] Park J H and Holloway P H 2005 J. Vac. Sci. Technol. B 23.2. 486.

[5] Tanimoto S, Kiritani N, Hoshi M and Okushi H 2002 Mat. Sci. Forum 389-393 879.

[6] Konishi R, Yasukochi R, Nakatsuka O, Koide Y, Moriyama M and Murakami M 2003 Mater. Sci. Eng. B 98286.

[7] Vassilevsk K, Zekentes K, Tsagaraki K, Constantinidis G and Nikitina I 2001 Mater. Sci Eng. B 80370.

[8] Johnson B J and Capano M A 2003 Solid-State Electronics 471437.

[9] Johnson B J and Capano M A 2004 J. Appl. Phys. $95 \mathrm{~N}^{\circ} 105616$

[10] Crofton J, Beyer L, Williams J R, Luckowski E D, Mohney S E and Delucca J M 1997 SolidState Electronics 411725.

[11] Crofton J, Porter L M and Williams J R, 1997 Phys. Stat. Sol. (b) 202, 581.

[12] Moscatelli F, Scorzoni A, Poggi A, Cardinali G C and Nipoti G 2003 Semicond. Sci. Technol. 18554.

[13] Scorzoni A, Moscatelli F, Poggi A, Cardinali G C and Nipoti R 2004 Mat. Sci. Forum 457460881.

[14] Kakanakov R, Kassamakova L, Kassamakov I, Zekentes K and Kuznetsov N 2001 Mater. Sci. Eng. B 80374.

[15] Crofton J, Mohney S E, Williams J R and Isaacs-Smith T 2002 Solid-State Electronics 46109.

[16] Chase M W, Davies C A, Downey J R, Frurip D J, McDonald R A and Syverud A N 1985 JANAF Thermochemical Tables, J.Phys.Chem.Ref.Data Vol. 14 Sup.1.

[17] Lee S K, Zetterling C M, Ostling M, Palmquist J P and Jansson U 2002 Microelectronic Engineering 60261.

[18] Porter L M and Davis R F 1995 Mater. Sci. Eng. B34 83.

[19] Nikitina I P, Vassilevski K V, Wright N G, Horsfall A B and O'Neill A G 2005 J. Appl. Phys. 97083709.

[20] Soueidan M, Lazar M, Nguyen D M, Tournier D, Raynaud C and Planson D 2009 Mat. Sci. Forum. 615-617 585.

[21] Laariedh F, Lazar M, Cremillieu P, Leclercq J-L, Planson D 2012 Mat. Sci. Forum. 711 169. 